\title{
GAS TURBINE SIZE OPTIMIZATION IN A HYBRID SYSTEM CONSIDERING SOFC DEGRADATION
}

\author{
A.Cuneo*, V. Zaccaria**, D. Tucker *** and A. Sorce* \\ *Thermochemical Power Group, Università di Genova, Via Montallegro 1, 16145, Genova, (Italy) \\ ** Mälardalen University, Högskoleplan 1, 72320 Västerås (Sweden)
}

*** U.S. DOE National Energy Technology Laboratory, 3610 Collins Ferry Rd., 26507 Morgantown, WV (USA)

\begin{abstract}
The coupling of a pressurized solid oxide fuel cell (SOFC) and a gas turbine has been proven to result in extremely high efficiency and reduced emissions. The presence of the gas turbine can improve system durability compared to a standalone SOFC, because the turbomachinery can supply additional power as the fuel cell degrades to meet the power request. Since performance degradation is an obstacles to SOFC systems commercialization, the optimization of the hybrid system to mitigate SOFC degradation effects is of great interest. In this work, an optimization approach was used to innovatively study the effect of gas turbine size on system durability for a $400 \mathrm{~kW}$ fuel cell stack. A larger turbine allowed a bigger reduction in SOFC power before replacing the stack, but increased the initial capital investment and decreased the initial turbine efficiency. Thus, the power ratio between SOFC and gas turbine significantly influenced system economic results.
\end{abstract}

Index Terms - hybrid systems, design optimization, SOFC degradation, and economic analysis

\section{NOMENCLATURE}

$\begin{array}{ll}\text { Abbreviation } & \\ \text { CFN } & \text { Annual cash flow } \\ \text { DLR } & \text { Deutsches Zentrum für } \quad \text { Luft-und } \\ \text { Raumfahrt } & \\ \text { EOL } & \text { End of life } \\ \text { FC } & \text { Fuel cell } \\ \text { GA } & \text { Genetic algorithm } \\ \text { GT } & \text { Gas turbine } \\ \text { IRR } & \text { Internal rate of return } \\ \text { HS } & \text { Hybrid system } \\ \text { LHV } & \text { Low heating value } \\ \text { LSM } & \text { lanthanum strontium magnetite } \\ \text { mGT } & \text { micro gas turbine } \\ \text { PID } & \text { Proportional integral derivative } \\ \text { SOFC } & \text { Solid oxide fuel cell } \\ \text { TCI } & \text { Total capital investment } \\ \text { TIT } & \text { Turbine inlet temperature } \\ \text { YSZ } & \text { yttria-stabilized zirconia }\end{array}$

Variables

C $\quad$ cost $[€]$ E FU i $\mathrm{h}$ $\mathrm{m}$ $\eta$

Q rd $\mathrm{P}$ $\mathrm{R}$ T Subscript el f in irr main nom ohm out

fuel

inlet

ohmic

outlet energy [kW]

fuel utilization [\%]

current [A]

enthalpy [kJ kg-1]

mass flow rate [kg s-1]

efficiency [\%]

fuel cell thermal output [kW]

degradation rate [\% kh- 1$]$

power [kW]

area specific resistance $[\Omega \mathrm{m} 2]$

temperature $\left[{ }^{\circ} \mathrm{C}\right]$

electrical

irreversible

maintenance

nominal

\section{INTRODUCTION}

Due to the growing global energy consumption, high prices of energy, decreasing fossil fuel resources, and increasing local and global environmental concerns, finding an appropriate way for efficient power generation with low emissions has become a matter of issue. In particular, three desirable features for future energy solutions are mandatory: diversity in primary energy sources and generation technology, improved efficiency in energy conversion and use, and optimally matching energy technologies and resources to specific uses. Hence, energy technologies of the future require high efficiency, low emissions, scalability, and dispatchability. The fuel cell power generation system is considered to be a good candidate for future power production owing to its high-thermal efficiency and low pollutant emissions [1]. Among various types of fuel cells, solid oxide fuel cell (SOFC) is the most suited one for distributed power generation owing to its high efficiency even at small scale, low environmental pollution, fuel flexibility, and high-temperature exhausts suitable for thermal recovery. Because cost and durability currently limit SOFC technology commercialization [2] [3] [4], different solution are proposed in literature combining the SOFC with other different technologies [5] [6] [7]. Among the 
variety of SOFC-based combined cycles proposed to date, pressurized SOFC-gas turbine (GT) integration has attracted significant attention because of its high efficiency potential (i.e., theoretically approaching $75-80 \%$ on natural gas (LHV)) [8]. Such systems are able to simultaneously solve some of the key problems of small gas turbines (low efficiency and NOx emissions due to the combustor) and of SOFCs (high cost, predicted to be around \$800-1200 per kW).

In such systems, the topping SOFC stack and bottoming GT are directly (i.e., chemically and thermally) coupled, as SOFC exhaust gases are directly fed to the bottoming cycle. Hence, the pressurized SOFC module substitutes the combustor of the regenerated turbine plant, and the clean effluent has a temperature of about $900^{\circ} \mathrm{C}$, which well matches the requirements on the inlet temperature of first generation micro-turbines. Fuel cell gas turbine (FC/GT) hybrid technology demonstrated fuel-to-electricity conversion efficiency as high as $56 \%$ (lower heating value (LHV)) [9] and theoretical plant efficiencies exceeding 75\% [10]. Fuel cell-gas turbine hybrid technology has demonstrated the ultrahigh efficiency, ultralow emissions, and fuel flexibility necessary to achieve local, state, and federal targets for future energy conversion [11] [12] [13], and are the preferred option to reach the targets set by the European 2020.

Integrated SOFC/microturbines (hybrid systems) are at an early stage of testing at the moment [14], and technicaleconomic optimization is an issue currently being addressed by many developers. In prototype and pilot-scale plants, normally the SOFC generates most of the power, working with fairly high fuel utilization and high stack efficiency. For example, Rolls Royce Fuel Cell Systems (now LG Fuel Cell Systems) presented in 2007 a 2 MW system prototype where the SOFC produced 4 times the power of the gas turbine [15]. Siemens' hybrid system featured a $180 \mathrm{~kW}$ SOFC coupled with a $40 \mathrm{~kW}$ micro gas turbine [16]. In the $200 \mathrm{~kW}$ hybrid system developed by Mitsubishi Heavy Industries, the SOFC produced $183 \mathrm{~kW}$ [16]. There has been general agreement in the literature that the most efficient component (i.e. the stack) should contribute around 70-90\% to the total power generation [18] [19] [20] [20] [22].

Different SOFC/GT emulator are also available around the world and all of them work with a high power share. For example, the emulator installed in Savona (Italy) from the ThermoChemical Power Group [22] [24] [25] [26] coupled a $100 \mathrm{~kW}$ of mGT to a $450 \mathrm{~kW}$ SOFC. The emulator installed at Deutsches Zentrum für Luft-und Raumfahrt (DLR) in Germany, based on Siemens work [27] [28] is based on a power stack ten times the mGT power. However, system performance optimization has been normally considered in design conditions, without considering stack performance degradation over time and its consequences on plant operations.

Mechanisms limiting SOFC operating life have been widely investigated [29] [30] [31] [32]. The Authors already analysed the effect of fuel cell degradation on the hybrid systems performance and economic return in a previous work [33]. In that study, it was suggested that a design in which fuel cell stack and gas turbine are about the same size could extend fuel cell durability and be beneficial from an economic point of view. However, no optimization analysis was performed to understand the optimal power share between SOFC and mGT in a hybrid system. In this respect, this study would like to fill this gap optimizing the mGT size with respect to the Internal Rate of Return (IRR). This economic parameter was chosen since it takes into account both energetic (electrical energy selling, fuel consumption) and economic (capital cost) contribution.

The aim of this paper is to evaluate the effect of the mGT size on the system durability considering the SOFC degradation, given a fuel cell stack size of $400 \mathrm{~kW}$. Based on the control strategy employed in previous work [33], the initial size of the turbine would determine the life of the fuel cell. A larger turbine size allows a bigger reduction in SOFC power before replacing the stack, but increases the initial capital investment and decreases the initial turbine efficiency, because the machine has to operate in off-design condition. The optimal size was evaluated, in this work, by maximizing the IRR of the plant. Unlike similar previous work, fuel cell performance degradation over time was considered for the design optimization of the hybrid system.

\section{MODEL DESCRIPTION}

The model used in this analysis is a 1D model to simulate a co-flow, planar anode-supported SOFC, composed of a Ni doped yttria-stabilized zirconia (Ni-YSZ) anode, an YSZ-lanthanum strontium magnetite (LSM) cathode, and YSZ electrolyte [35]. The model was previously developed with the aim of integrating it into a SOFC gas turbine hybrid system emulator [35] [36] [37] taking into consideration the degradation effects. The full description of the model is reported in [35] [36] [38] and it is here summarized. An overview of the hybrid system model is presented in Figure 1. 


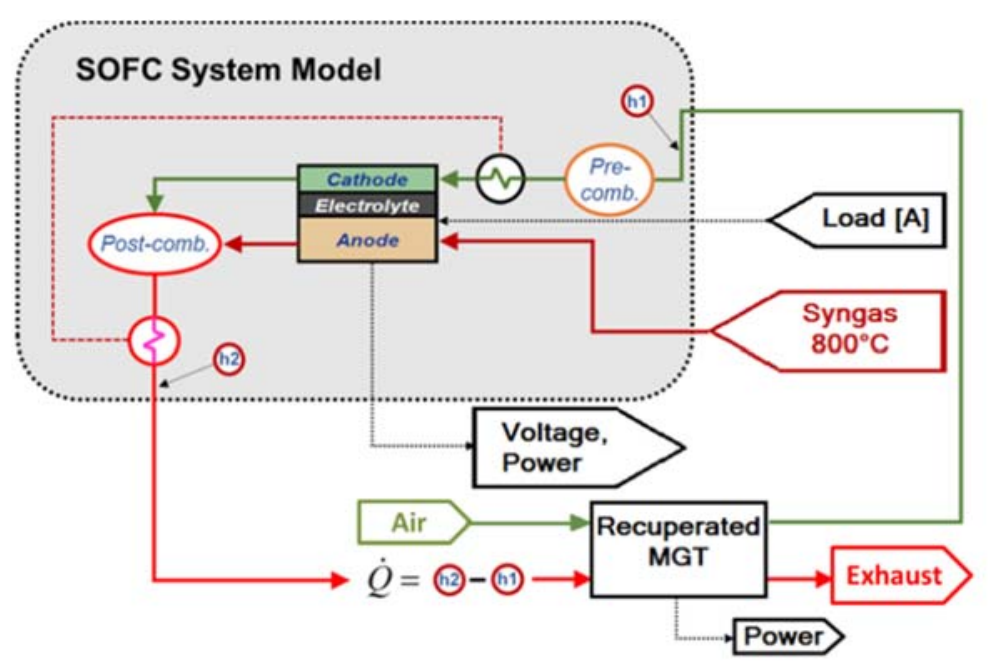

Fig. 1. Schematic layout of the hybrid system model

The model employs a coupled approach of finite difference and finite volume for thermal and electrochemical equations, respectively. Since the electrochemistry models do not use differential equations, the finite volume approach is more appropriate, while for heat transfer a finite difference method is applied as it is the optimal compromise between short computational time and accuracy in capturing the transients. More details on equations, parameters, and model validation can be found in Hughes et al. [35]. The model includes a relationship to evaluate the SOFC degradation over time. The SOFC degradation expression was extrapolated from experimental data using a curve fitting approach [39] [40]. The data set referred to experiments performed at different values of current density, fuel utilization, and temperature. Degradation rate is calculated according with Equation (1) and incorporated into the total resistance of the cell as shown in Equations (2) and (3). Material set and fuel composition considered in this work are the same as those employed for the aforementioned experiments. The effect of degradation is an increment in the ohmic resistance $\mathrm{R}_{\text {ohm. }}$. Degradation contribution is expressed in terms of the coefficient $r_{d}$ (percentage of voltage drop per $1000 \mathrm{~h}$ of operation) and with the term $\mathrm{R}_{\text {irr, }}$ which represents the irreversible contribution of degradation and whose value is updated at each sample time.

$$
\begin{gathered}
r_{d}=\frac{0.59 \cdot F U+0.74}{1+\exp \left(\frac{T-1087}{22.92}\right)} \cdot\left(e^{2.64 \cdot i}-1\right) \\
R=\left(R_{\text {ohm }}+R_{\text {irr }}\right) \cdot\left(1+r_{d} \cdot \frac{t}{1000}\right) \\
R_{\text {irr }}=\sum_{\text {time }} R_{\text {ohm }} \cdot \frac{r_{d}}{1000}
\end{gathered}
$$

The thermal power from the fuel cell stack is calculated from the difference in specific enthalpy variation of the gas stream, illustrated in Equation 4. The thermal power is converted into electric power in the turbine model, as shown in Equation 5.

$$
\begin{gathered}
\dot{Q}=\dot{m}_{\text {out }} h_{\text {out }}-\dot{m}_{\text {in }} h_{\text {in }} \\
P=\eta_{G T} \cdot \dot{Q}
\end{gathered}
$$

The recuperated gas turbine cycle is modeled as a black box, based on a map of the recuperated cycle efficiency as function of generated power. The efficiency $\eta_{\mathrm{GT}}$ as function of power is plotted in Figure 2. 


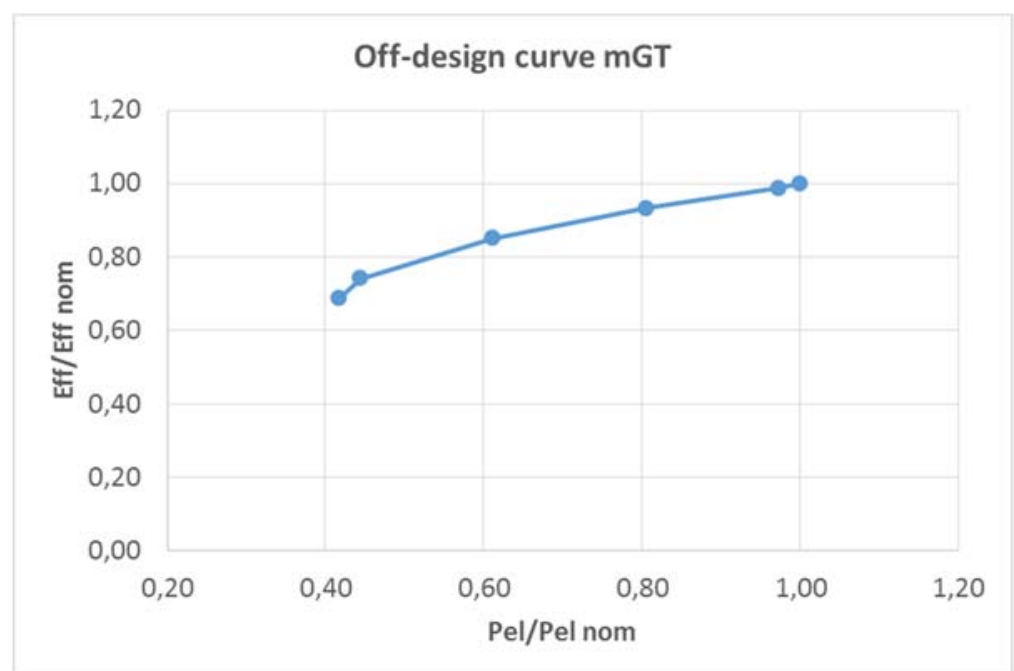

Fig. 2. Gas turbine cycle efficiency map

Since the optimization algorithm chooses a different mGT size at each iteration, a curve to relate the nominal mGT efficiency with the mGT size was implemented. From the work of [41] different points were taken into account related to different gas turbines (Table 1).

TABLE I

EXPERIMENTAL DATA FROM DIFFERENT TURBINE

\begin{tabular}{|c|c|c|c|c|}
\hline \multicolumn{2}{|c|}{ Type of turbine } & $\begin{array}{c}\text { Power } \\
{[\mathbf{k W}]}\end{array}$ & $\begin{array}{c}\text { Efficiency } \\
{[\%]}\end{array}$ & Reference \\
\hline- & AlliedSignal & 75 & 27,3 & {$[41]$} \\
\hline TA 45 & Elliott Energy System & 45 & 30 & {$[41]$} \\
\hline TA 80 & Elliott Energy System & 80 & 30 & {$[41]$} \\
\hline TA 200 & Elliott Energy System & 200 & 30 & {$[41]$} \\
\hline C30 & Capstone & 30 & 26 & {$[41]$} \\
\hline C65 & Capstone & 65 & 29 & {$[41]$} \\
\hline- & Power WorksTM & 70 & 27,3 & {$[41]$} \\
\hline MT 100 & ABB & 100 & 30 & {$[41]$} \\
\hline C200 & Capstone & 200 & 33 & {$[41]$} \\
\hline C600S & Capstone & 600 & 33 & {$[45]$} \\
\hline C800S & Capstone & 800 & 33 & {$[45]$} \\
\hline C1000S & Capstone & 1000 & 33 & {$[45]$} \\
\hline
\end{tabular}

A correlation between design efficiency and power was then found as shown in Figure 3.

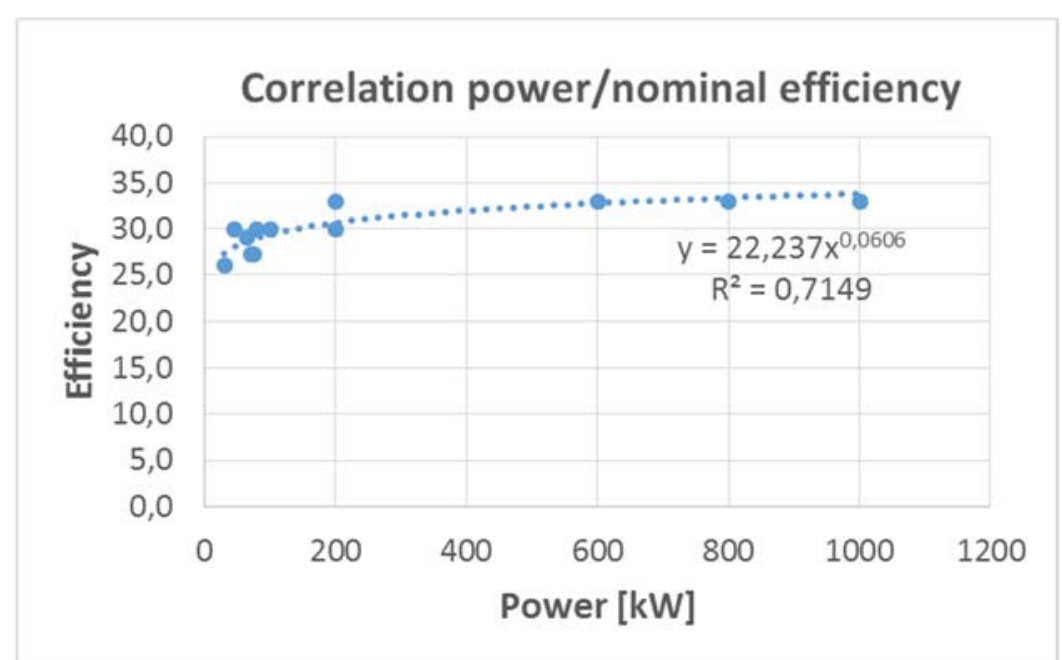

Fig. 3. Correlation between mGT power and design efficiency 
In a previous work, a constant cell voltage operating mode was selected as the most economically beneficial [33]. Constant voltage operation was proven to extend SOFC lifetime by other authors [42]. The same operating strategy is applied in this study, in which fuel cell voltage and total system power are maintained constant. The latter target could be achieved by increasing the load to the turbine as the cell power is degrading. Anode fuel flow is incremented to increase turbine inlet temperature (TIT) and thus the turbine power output. Since there is no need to maintain cell power constant, cell current is decreased by a PID controller in order to reduce degradation and keep constant voltage. As the current decreases, cathode air flow is regulated by varying a bypass valve to maintain constant $\Delta \mathrm{T}$ across the cell. The nominal operating parameters are reported in Table 2.

TABLE II

NOMINAL OPERATING CONDITIONS

\begin{tabular}{|l|c|}
\hline \multicolumn{2}{|c|}{} \\
\hline Number of cells & 2450 \\
\hline Current [A] & 200 \\
\hline Airflow [kg/s] & 1.1 \\
\hline Voltage [V] & 0.82 \\
\hline Design TIT $\left[{ }^{\circ} \mathbf{C}\right]$ & 950 \\
\hline Total power $[\mathbf{k W}]$ & 500 \\
\hline Stack power $[\mathbf{k W}]$ & 400 \\
\hline
\end{tabular}

A simple economic analysis was implemented to evaluate the IRR. The economic analysis is based on the life cycle of the first SOFC stack, and not on the whole lifetime of the plant. In other words, the replacement of stacks onto the same balance of plant has not been considered. Hence, firstly the condition for the End of Life (EOL) was determined, then the economic parameters were calculated based on this period. The EOL was evaluated as the turbine power reached the considered design condition, since total system power cannot be maintained constant after that point. The optimization problem was set to find the best mGT size to maximize the IRR at the EOL of the fuel cell stack. The fixed costs for the economic analysis included the capital cost of the hybrid systems (mGT+SOFC), and the variable costs considered fuel consumption, electrical power production, and a fixed percentage for annual maintenance cost. The IRR was evaluated with Equations 6 and 7.

$$
\sum_{j=1}^{\mathrm{EOL}} \frac{\mathrm{CFN}_{\mathrm{j}}}{(1+\mathrm{IRR})^{\mathrm{j}}}-\mathrm{TCI}=0
$$

Where:

$$
\mathrm{CFN}_{\mathrm{j}}=\mathrm{E}_{\mathrm{el}} \mathrm{P}_{\mathrm{el}, \mathrm{j}}-\mathrm{C}_{\mathrm{f}} \mathrm{P}_{\mathrm{f}, \mathrm{j}}-\mathrm{C}_{\text {main }, \mathrm{j}}
$$

The assumptions for the calculation of the economic parameters were the following, in line with the assumption made in previous works [33] referring to USA market:

- an initial investment of $\$ / \mathrm{kW} 1000$ for the FC stack, considering a $400 \mathrm{~kW}$ stack and $1 \%$ of the stack cost for ancillaries [43];

- revenue of $\$ / \mathrm{kWh} 0.14$ for electric power produced considering a feed-in tariff in order to favor SOFC early penetration in the market;

- a cost of $\$ / \mathrm{kg} 0.1(\$ / \mathrm{kJ} 2.4 \cdot 10-6)$ of fuel considering the price of natural gas [44]; although the simulated fuel composition was a typical syngas employed to extrapolate the degradation model, for simplicity in this study a gasifier or fuel processing units was were not considered in the economic analysis;

- $3 \%$ of the total investment cost for the annual maintenance cost;

- $\quad$ an internal rate of $1 \%$ to actualize the cash flows.

Since at each step the mGT size changes, based on the optimization algorithm, a fixed cost for the mGT cannot be applied. For these reason, starting from industrial data [43] a cost function for the mGT cost was implemented in the code. 


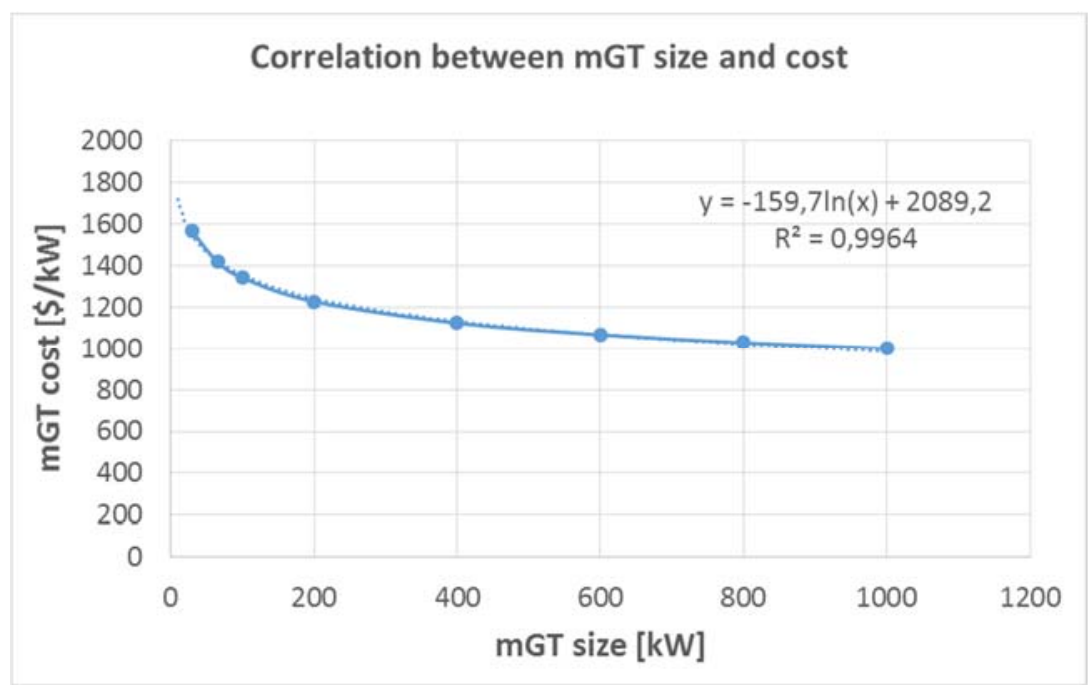

Fig. 4. mGT cost function

\section{RESULTS}

The first results obtained are related to the optimization of the mGT size in the hybrid system. For the optimization problem, the toolbox GA algorithm implemented in Matlab was used [46]. Genetic Algorithm is an adaptive heuristic search algorithm based on the evolutionary ideas of natural selection and genetics. Although randomised, GAs are by no means random, instead they exploit historical information to direct the search into the region of better performance within the search space. The key advantage of using GA is the capability of this method to search in parallel, employing a population of points, which helps it to avoid being trapped in a local optimal solution. Each individual represents a point in a search space and a possible solution. The individuals in the population are then made to go through a process of evolution. This method works in the way that after formation of an initial population of solutions as individuals as different sets of design parameters, pairs of these individuals are selected randomly and they compete in terms of superior gens to form next generations that fulfill the survival of fittest in the nature. With repetition of this procedure for a number of consecutive generations, the results approach to the optimum solution for the system [47]. By taking advantage of genetic operators like crossover, mutation and selection, solutions become fitter and fitter as search starts, and finally it converges to a single solution. Mutation options determine how the GA makes small random changes in the individuals in the population to generate mutation children. Moreover, choice of parents for the next generation is done in the selection stage. Crossover options specify how the GA combines two individuals to form a crossover child for the next generation. GAs simulate the survival of the fittest among individuals over consecutive generation for solving a problem.

A simple scheme for the GA algorithm procedure is represented in Figure 5. The parameters for use with the genetic algorithm are listed in Table 3 where the stopping criterion for the algorithm has been set to a specified number of generations. These parameters were set based on this specific problem, considering both accuracy and time consuming. In particular, the values related to the population and to the maximum number of generations were evaluated looking at the convergence of the optimization algorithm. In the Matlab toolbox, a real-time graph of the convergences of the algorithm is provided, then, a decision about the maximum number of generations was based on it. 


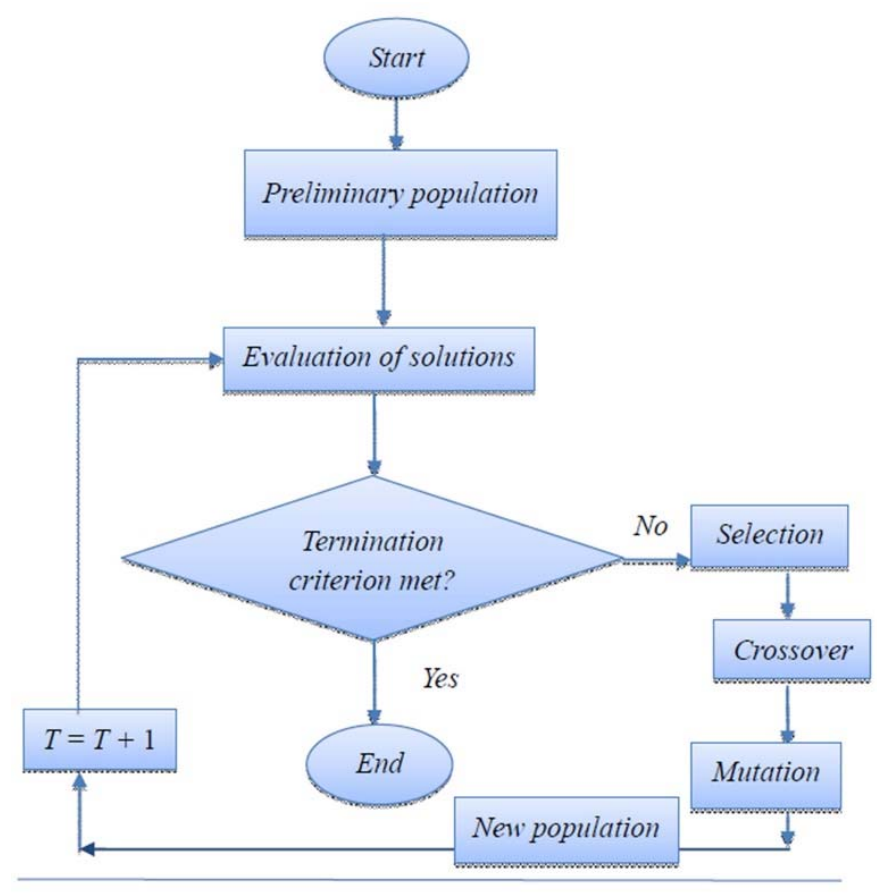

Fig. 5. Genetic algorithm procedure

TABLE III

GENETIC ALGORITHM OPTIMIZATION TUNING PARAMETERS

\begin{tabular}{|c|c|}
\hline Parameter & Value \\
\hline Population & 120 \\
\hline Maximum number of generations & 100 \\
\hline Probability of crossover & 0.8 \\
\hline Probability of mutation & 0.01 \\
\hline Migration Factor & 0.5 \\
\hline Selection process & Roulette \\
\hline
\end{tabular}

The objective function to maximize is the IRR and the decision variable the mGT size. The range between the mGT size should vary is evaluated from the stack power and the total power. In fact, since the total power is set equal to $500 \mathrm{~kW}$, the maximum mGT power is $500 \mathrm{~kW}$. In this condition the FC stack arrive at null power. On the other hand, since the stack power is $400 \mathrm{~kW}$, the minimum GT size to get the total power is $100 \mathrm{~kW}$. Between this range, the optimization problem found the optimum mGT size.

Table 4 shows the main results for different mGT size. Looking at the table is clear that small mGT sizes allow a low capital cost but the fuel cell life is very short and the plant results not economically convenient. On the other hand, a large mGT allows for a longer FC life but with an important capital investment. In addition, an important increase of FC life happen varying the mGT size from $350 \mathrm{~kW}$ to $400 \mathrm{~kW}$. Just $50 \mathrm{~kW}$ more in the mGT design power allow an increase of the FC life of 13 years, thanks to the related SOFC degradation mitigation. This fact can be explained because with the employed control strategy, the voltage degradation rate decreases over time as the current drawn from the fuel cell is decreased. Hence, the effect of degradation was lower as time proceeded, and lifetime extension became more pronounced when the stack power was allowed to decrease more. In the selected power range, the optimum appeared to be between 350 and $450 \mathrm{~kW}$. Under the hypothesis made the optimum seems to be between 350 and $450 \mathrm{~kW}$. Even if in Table 4 the FC life is reported with decimal number, the economic analysis for the IRR evaluation was performed round up to the next integer, to consider the entire year even if it is only partial.

TABLE IV

MAIN PARAMETERS FOR DIFFERENT MGT SIZE

\begin{tabular}{|l|c|c|c|c|c|c|}
\hline mGT size [kW] & 190 & 250 & 300 & 350 & 400 & 450 \\
\hline mGT design efficiency [\%] & 0.306 & 0.311 & 0.314 & 0.317 & 0.320 & 0.322 \\
\hline Capital cost [k\$] & 557.7 & 621.9 & 673.5 & 723.8 & 772.9 & 821.1 \\
\hline FC life [Years] & 0.43 & 1.19 & 2.64 & 6.53 & 19.41 & 39.86 \\
\hline IRR [\%] & -0.799 & -0.520 & -0.175 & 0.068 & 0.126 & 0.101 \\
\hline
\end{tabular}


Figure 6 shows both the power share between SOFC and mGT for four different mGT size and the efficiency profiles.
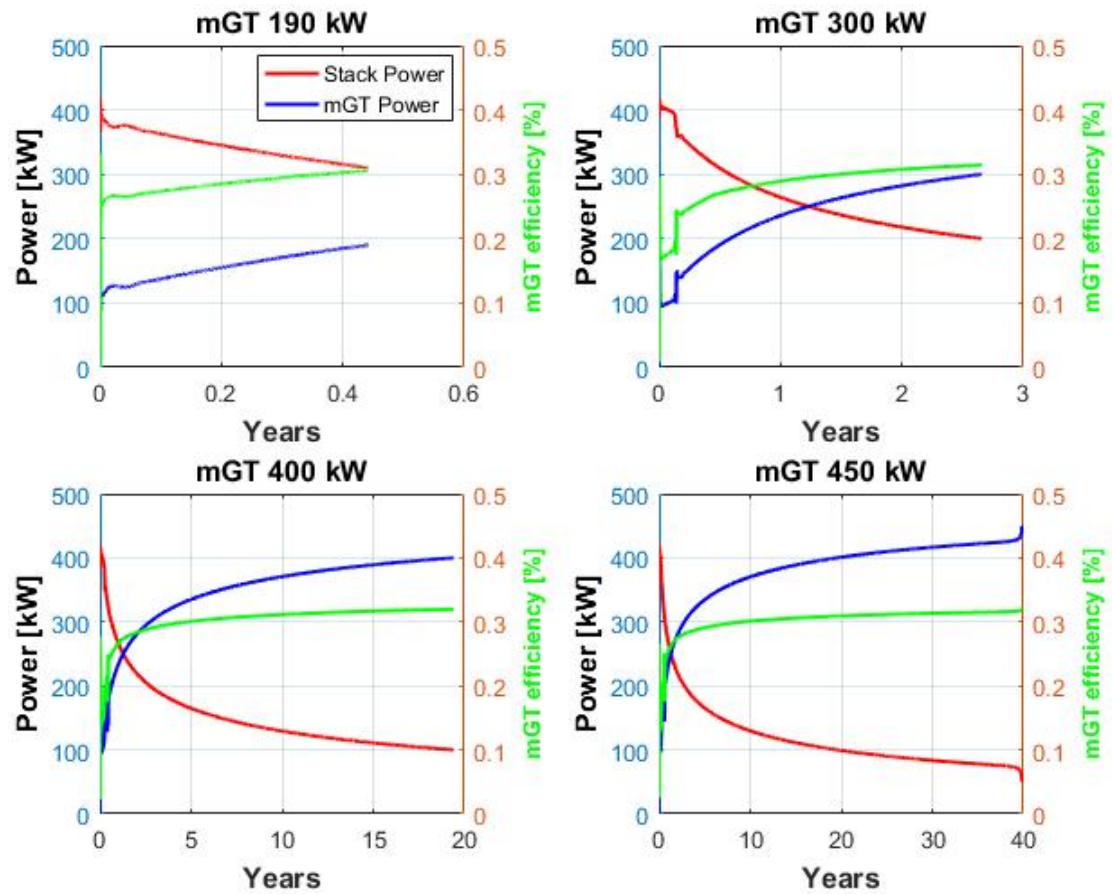

Fig. 6. Power share and mGT efficiency for different mGT size

As explained before, the mGT works in a strong off-design condition at the beginning of the life. Looking at the mGT efficiency profile (Figure 6), the mGT start to work with 50\% of the nominal efficiency (in mGT $400 \mathrm{~kW}$ case), reaching the nominal value only at the end of the life.

Related to the economic analysis, the trend of the cash flow during the FC life is represented in Figure 6. In particular, it is highlighted the behavior both of the fuel consumption cost and the electricity selling revenues. While the electricity selling remained more or less constant during the entire life, except the last year, the fuel consumption increased due to the reduction in the overall system efficiency, with the increase of the mGT power share and the anode fuel flow increment. This led to a decrease of the total cash flow. In particular, for mGT size equal to 400 and $450 \mathrm{~kW}$, the decrease was higher in the first five years of the life, becoming more constant in the middle of the life and increasing again in the last year. In particular, in all cases, in the last year there is an important reduction in the electrical energy and fuel consumption because it was not a complete year of operations but the mGT design conditions were reached after few months. For this reason, in the last year the two points related to the electricity and fuel are lower than the year before, but the ratio between sold electricity revenues and fuel consumption follows the previous efficiency related trend. 

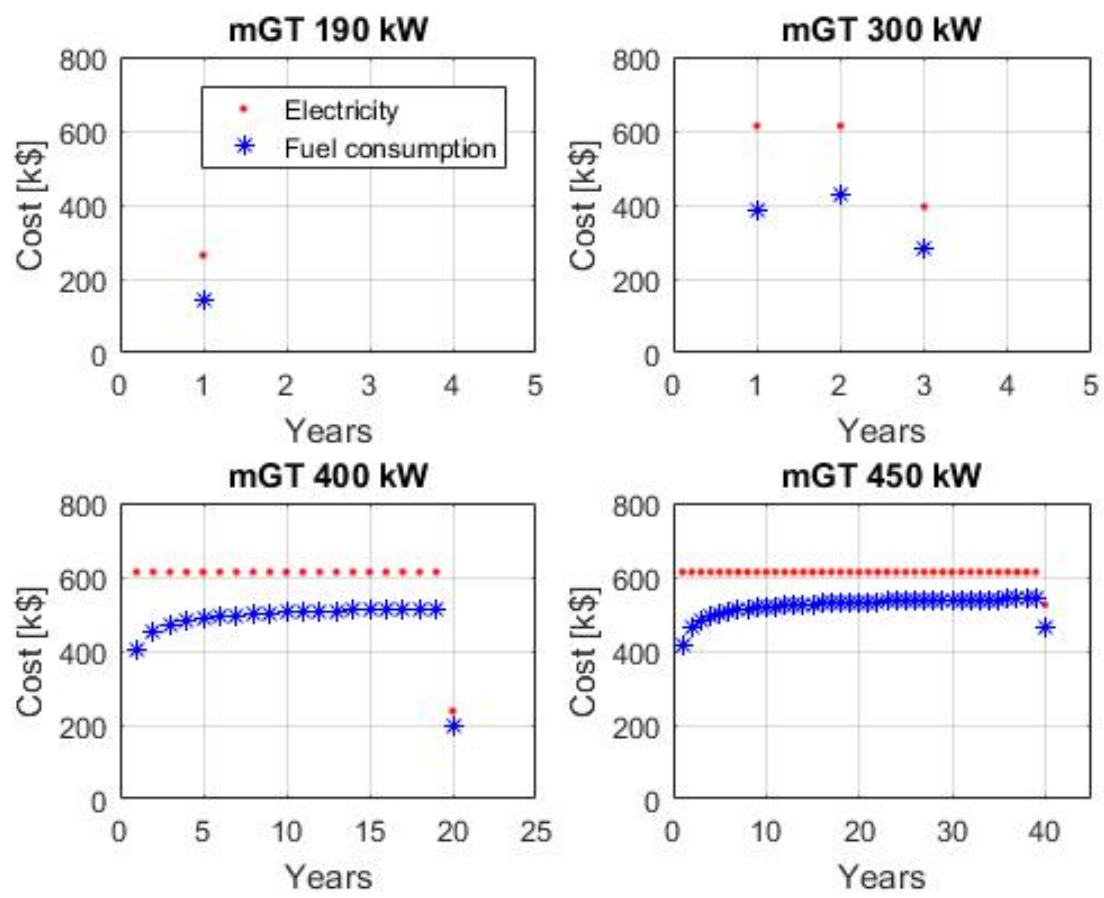

Fig. 7. Cash Flow during the entire life of the plant for different mGT size

The optimization algorithm found the optimum point for an mGT size equal to $403 \mathrm{~kW}$. Figure 8 shows the IRR around the optimum point (the red one).

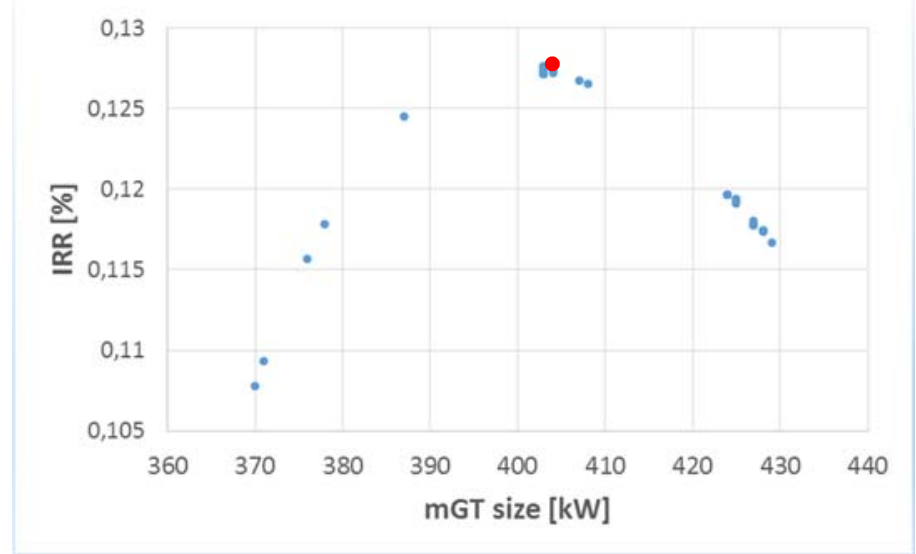

Fig. 8. Optimization points

The main parameters of the optimum point are reported in Table 5.

TABLE V

MAIN PARAMETERS OF THE OPTIMUM POINT

\begin{tabular}{|l|l|}
\hline & \\
\hline mGT size [kW] & 403 \\
\hline mGT design efficiency [\%] & 0.321 \\
\hline mGT capital cost [k\$] & 775.9 \\
\hline FC life [yrs] & 21 \\
\hline IRR [\%] & 0.128 \\
\hline
\end{tabular}

The results showed that the best economic condition to work with this kind of systems, is to share the power between SOFC and $\mathrm{mGT}$ with a percentage of nearly $50 \%$, confirming the assumption made in previous work. In this way, the capital cost of the mGT is quite high but, since the plant work for a longer period, the capital cost are covered by the revenues from the electrical energy sold to the grid.

For a clearer explanation of the hybrid system operations in this optimal design condition, different key-parameters were analyzed in more details. The voltage controller gradually decreased the current load, as Figure 9 shows, in order to obtain 
a double effect: a decrement in fuel utilization allowed to increase Nernst potential, offsetting the voltage loss due to degradation, which was additionally reduced thanks to the lower current density and fuel utilization.
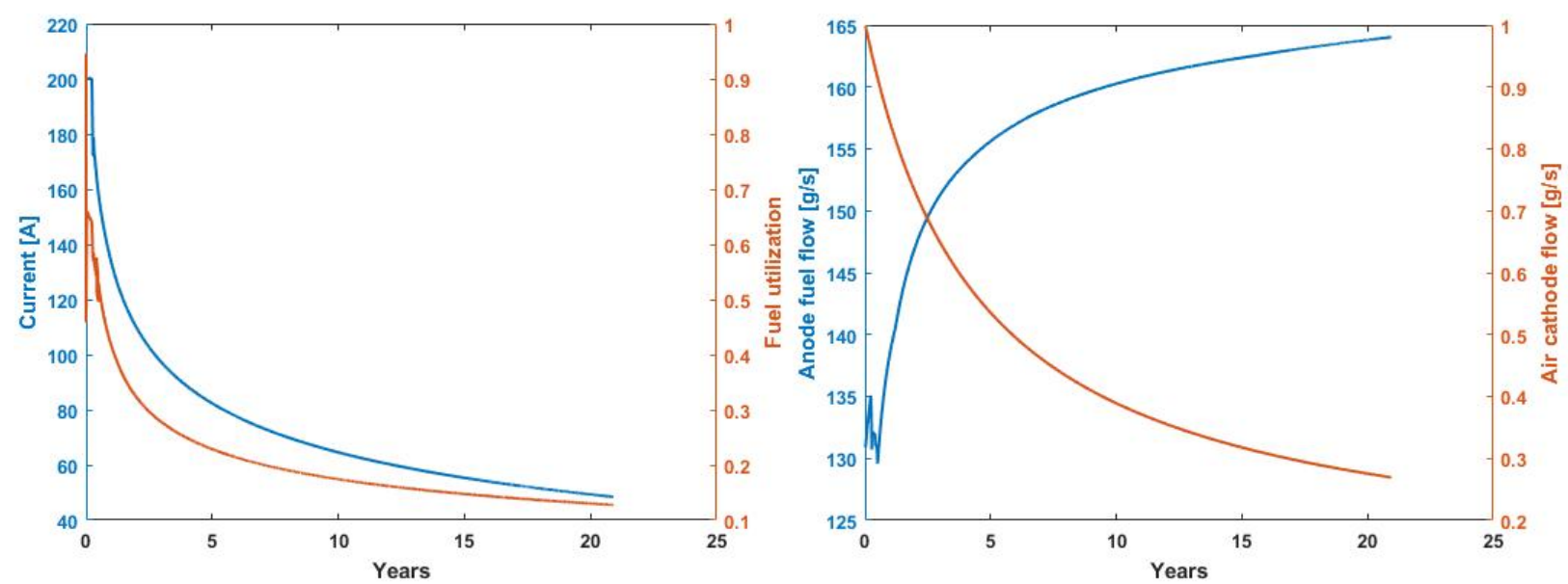

Fig. 9. Current profile and fuel utilization (left) and flow (right) profile along the time

To maintain the total power system constant, load was shifted to the turbine, increasing the fuel flow to the anode side (Figure 9) and consequently the thermal effluent from the cell to the gas turbine. Turbine load increased from $100 \mathrm{~kW}$ to $403 \mathrm{~kW}$ in 230,000 hours for the optimum point. The fuel flow needed to be increased to maintain the power output. Its increment was $20 \%$ in $230,000 \mathrm{~h}$, following a trend that mirrored the current tendency.

Due to the degradation, the stack efficiency decrease during time (Figure 10). In this respect, the shift load to the turbine, with the increase in the mGT efficiency, allow a not so important reduction on the hybrid system efficiency.

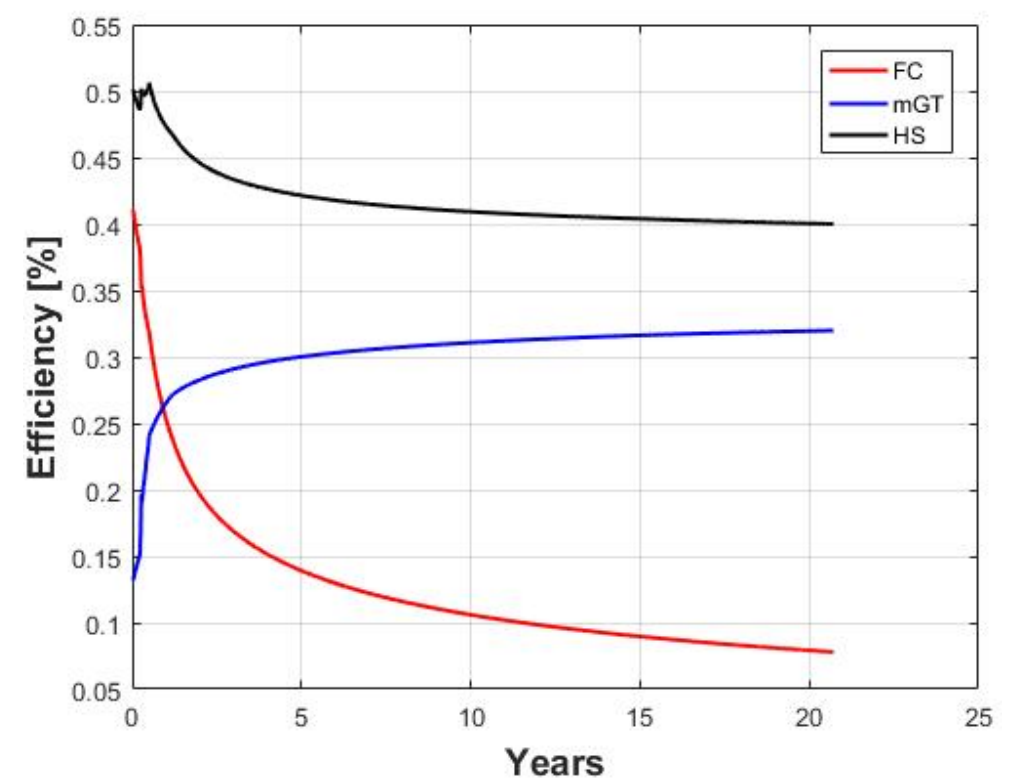

Fig. 10. Comparison between FC stack efficiency and mGT efficiency

A particular attention will now focused on the mGT size influence on the stack degradation. In particular, the main variables that affect fuel cell degradation and that represent stack performance are hereafter presented. The fuel cell stack model was discretized inside the model in 20 volumes of calculation in the direction of fuel and air flows. Hence, the model had the capability to display distributed profiles of the main variable along the cell over time. Local analysis of key performance parameters in the SOFC stack allowed to better understand the effect of the mGT coupling and the system operating strategy on fuel cell degradation.

The average current density was reduced, but on a local basis, current density decreased in the first half of the cell and substantially increased in the second half, as Figure 11 shows. A higher initial degradation of the cell inlet incremented the resistance in this part of the cell, shifting the current downstream. The current density distribution became more uniform as time proceeded and average current density decreased. The peak, initially located at node 7 , moved over time toward the end of the cell where the resistance was lower because the cell was less degraded. 

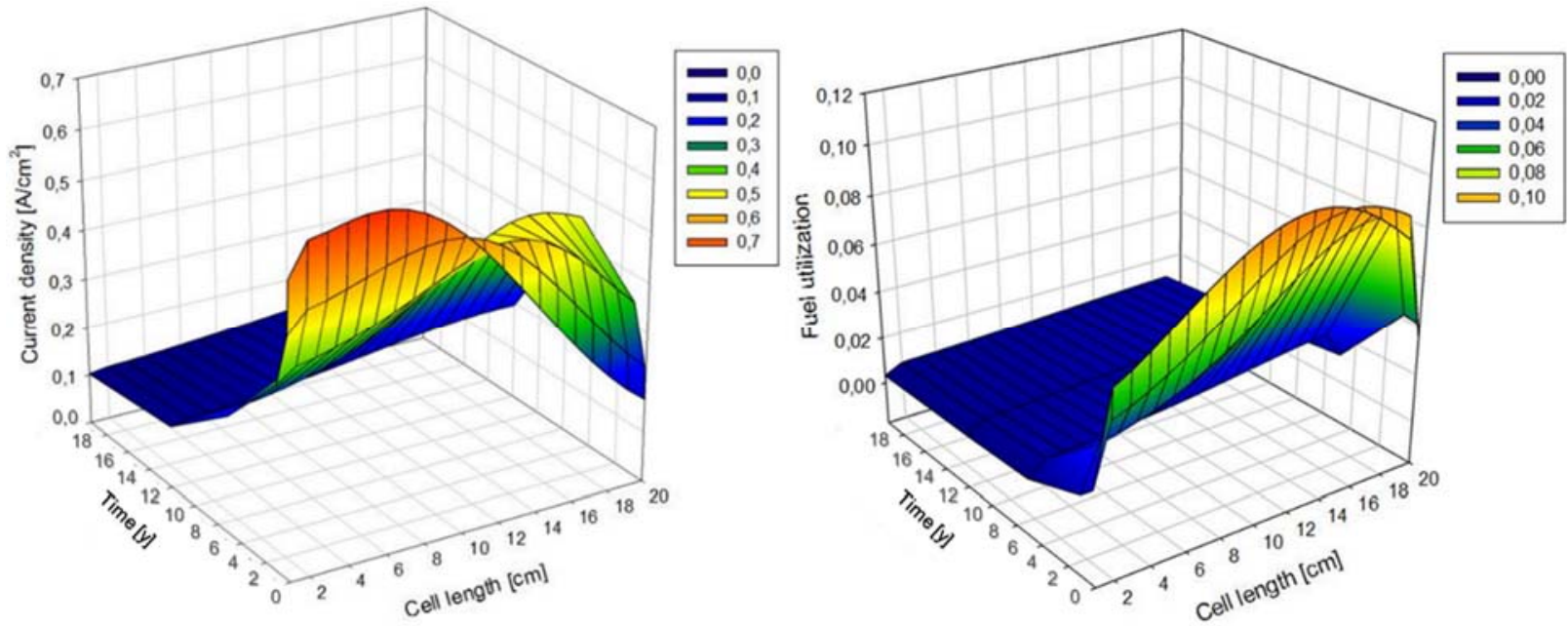

Fig. 11. Current density (left) and fuel utilization (right) profiles along the time

The local fuel utilization distribution did not change significantly, but it decreased substantially everywhere. The maximum was shifted toward the cell outlet as well, following the peak in current density, but overall the profile maintained a uniform distribution, as shown in Figure 11.

Cathode airflow was decreased to maintain constant temperature difference between outlet and inlet. The reduction in cooling flow influenced also the solid temperature distribution. A simultaneous regulation of cathode airflow and air preheat resulted in a quite constant temperature distribution over time, as illustrated in Figure 12. The temperature increased at the cell inlet and decreased at the outlet during the first 20,000 hours, and then it remained fairly constant until the end of life.
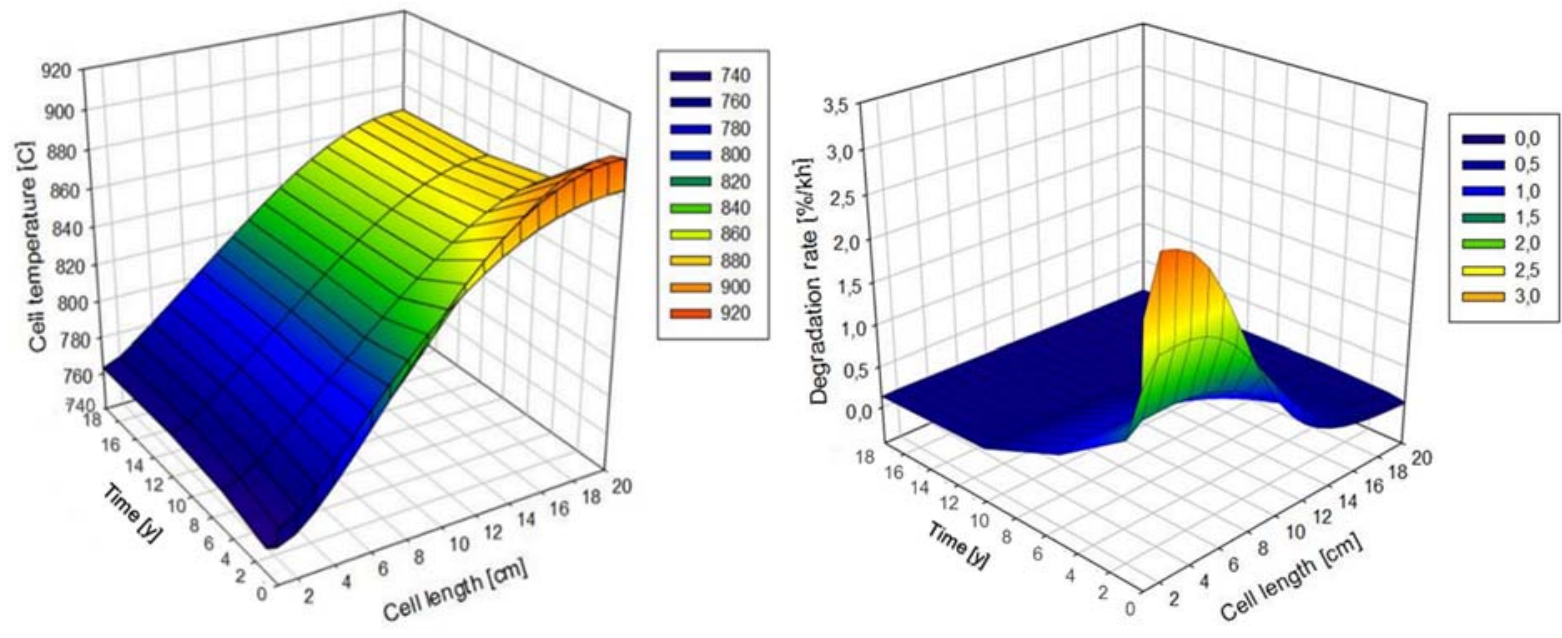

Fig. 12. Cell temperature (left) and degradation rate (right) profiles along the time

Looking with more emphasis on the degradation rate, shown in Figure 12, it decreased in the first part of the cell due to the reduction in current density and an increment in solid temperature. In the end of the cell, the decrement in current density kept the degradation rate low even though the solid temperature decreased. For this reason, after the first 5,000 hours, local degradation rate was substantially low everywhere, and after 100,000 hours, it was below $0.5 \%$ in every part of the cell.

The effect of localized degradation was to increment the fuel cell equivalent resistance with a cumulative, irreversible effect. Resistance profile, shown in Figure 13, always presented a higher value at the cell inlet where the temperature was lower, because of the inverse dependence of ohmic resistance on solid temperature. The resistance increased significantly in the first half of the cell, due to the cumulative effect of a higher degradation rate, and slightly at the end. In the long term, the reduced temperature had a big impact on the resistance, which increased in the last part of the cell although the degradation rate was low. Although the local degradation rate decreased over time, the total resistance kept increasing because of the cumulative degradation effect. A lower resistance at the cell outlet allowed the current density to increase in this part after the inlet degraded, as was shown in Figure 10. 


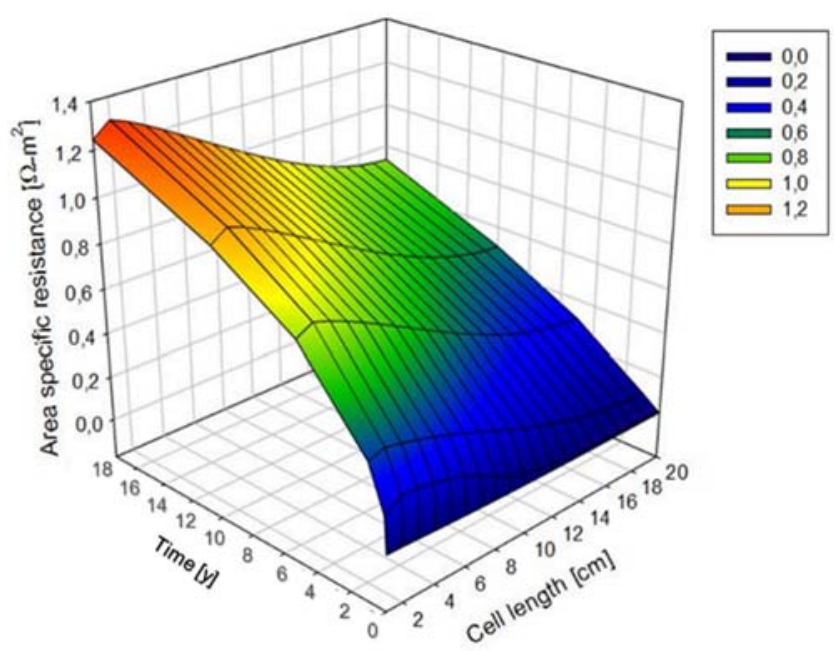

Fig. 13. Area specific resistance profiles along the time

To understand the contribution of different overpotentials on the total cell resistance, diffusion, activation and ohmic losses are shown in Figure 14. The figures show the contribution of the different losses to the total resistance. The first point to highlight is that the maximum total resistance is about the same both at time 0 and at the end of life and equal to $0.16 \Omega / \mathrm{cm} 2$. While at time 0 the total resistance has a peak in node 2 and decrease in the cell length, at the end of life the peak in the node 2 remain the same but it increases in the cell length becoming more uniform. Initially, the activation losses represented the major contribution, in particular at the cell inlet where the current density was higher and the temperature lower. Ohmic losses represented a fourth of the total overpotential and were quite uniform along the cell. Diffusion losses contributed for less than 5\% at the cell inlet and around 18\% at the outlet. Once the cell degraded completely, the ohmic losses became the major contribution to the total losses, around $90 \%$ in every part of the cell. This was driven by the increment in ohmic resistance due to a lower temperature and the degradation effect. The behavior of the current density (Figure 14) in both instant explain well the ohmic resistance profile. Activation losses contribution decreased to around $10 \%$ with a higher peak at the outlet where current density increased. Diffusion losses became negligible at the end of the life, due to the extremely low operating current and fuel utilization.
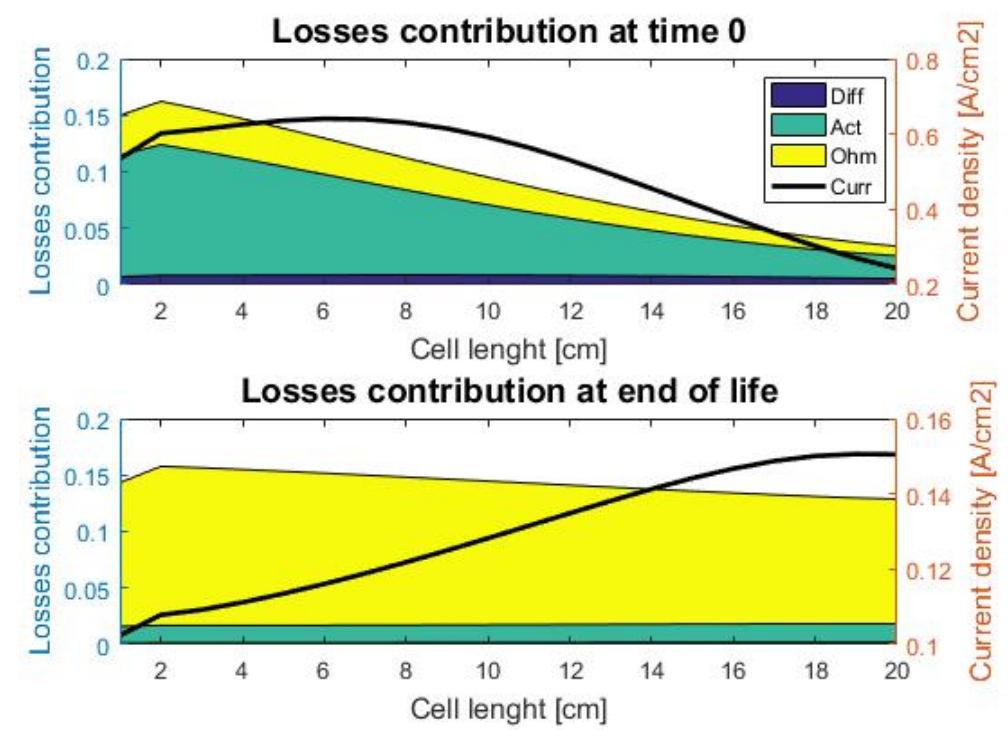

Fig. 14. Losses contribution and current density at time 0 and end of life.

\section{CONCLUSION}

An optimization study to understand the effect of the gas turbine size on system durability of fuel cell gas turbine hybrid systems was performed for the first time. The IRR was taken into consideration as the objective function to maximize. Fuel cell degradation was considered and a previously demonstrated operating strategy was employed. The results showed that from this point of view, an equal power share between SOFC and gas turbine at design conditions optimized the economic return of the plant, which differs from what is considered optimal balance of plant in the state of 
practice.

After evaluating the optimum gas turbine size from the economic point of view, a detailed analysis of the fuel cell performance, with a particular attention on the degradation contribution, was analyzed. The main conclusions are summarized as follow:

- A small mGT size allow a low capital cost but the fuel cell life is very low and the plant results not economically convenient. On the other hand, a large mGT allow a longer FC life but with an higher capital investment

- The optimum mGT size results in $400 \mathrm{~kW}$, equal to the FC stack power. In this condition the mGT works in a strong off-design condition at the beginning of the plant life $(50 \%$ of the nominal one) but it permits a longer FC life equal to 21 years

- The effect of localized degradation highlights the increment of the fuel cell equivalent resistance with a cumulative, irreversible effect

- With the proposed control strategy the reduction of FC load leads to the current density reduction and equalization, with almost constant losses along the cell length. The local reduction of degradation rate and consequent mitigation of losses increment explains why a greater power contribution from the mGT allows a longer fuel cell lifetime and a better system economic return.

- With the decrease of the utilization factor, Ohmic loss becomes the main contributor to the FC losses

Although in current pilot-scale plants, normally the SOFC generates most of the power, if the SOFC degradation is considered in the design process, the best economic condition to work with this kind of systems is to share the power between SOFC and mGT with a percentage of 50\%. Hence, in designing this kind of systems, the effect of SOFC degradation cannot be neglected. It was also demonstrated by the same authors in another work [48] that the optimum share between the mGT and fuel cell (around 50\%) is not influenced by the substitution of the turbine if the turbine degradation during life is considering together with the SOFC degradation.

\section{REFERENCES}

[1] Larminie, J., Dicks, A., Fuel cell systems explained (2nd ed.), John Wiley and Sons Ltd., West Sussex (2003)

[2] Noriko Hikosaka Behling Fuel Cells: Current Technology Challenges and Future Research Needs 2012

[3] Reyhani, H.A., Meratizaman, M., Ebrahimi, A., Pourali, O., Amidpour, M., Thermodynamic and economic optimization of SOFC-GT and its cogeneration opportunities using generated syngas from heavy fuel oil gasification, Energy, Volume 107, 2016, pp. 141-164

[4] D. Yan, C. Zhang, L. Liang, K. Li, L. Jia, J. Pu, L. Jian, X. Li, T. Zhang, Degradation analysis and durability improvement for SOFC 1-cell stack, Applied Energy Volume 175, 2016, pp. 414-420, https://doi.org/10.1016/j.apenergy.2016.04.094.

[5] Choudhury, A., Chandra. H., Arora, A., Application of solid oxide fuel cell technology for power generation-A review, Renewable and Sustainable Energy Reviews, Volume 20, 2013, pp 430-442

[6] V. Antonucci, L. Branchini, G. Brunaccini, A. De Pascale, M. Ferraro, F. Melino, V. Orlandini, F. Sergi, Thermal integration of a SOFC power generator and a Na-NiCl2 battery for CHP domestic application, Applied Energy, Volume 185, Part 2, 2017, pp. 1256-1267, https://doi.org/10.1016/j.apenergy.2016.04.051.

[7] F. Petrakopoulou, Y. D. Lee, G. Tsatsaronis, Simulation and exergetic evaluation of $\mathrm{CO} 2$ capture in a solid-oxide fuel-cell combined-cycle power plant, Applied Energy, Volume 114, 2014, pp. 417-425, https://doi.org/10.1016/j.apenergy.2013.09.034.

[8] Buonomano, A., Francesco, C., Dentice d'Accadia, M., Palombo, A., Vicidomini, M., Hybrid solid oxide fuel cells-gas turbine systems for combined heat and power: a review, Appl Energy, Volume 156, 2015, pp. 32-85

[9] FuelCell Energy Inc., Record Electric Efficiency for DFC/Turbine Unit, Fuel Cells Bull., 2006,

[10] Ghezel-Ayagh, H., Walzak, J., Patel, D., Daly, J., Maru, H., Sanderson, R., and Livingood, W., , State of Direct Fuel Cell/Turbine Systems Development, J. Power Sources, Volume 152, 2005, pp. 219-225

[11] S. K. Park, J. Ahn, T. S. Kim, Performance evaluation of integrated gasification solid oxide fuel cell/gas turbine systems including carbon dioxide capture, Applied Energy, Volume 88, Issue 9, 2011, pp. 2976-2987, https://doi.org/10.1016/j.apenergy.2011.03.031.

[12] Richards, G. A., McMillian, M. M., Gemmen, R. S., Rogers, W. A., and Cully, S. R., Issues for Low-Emission, Fuel-Flexible Power Systems, Prog. Energy Combust. Sci., Volume 27, 2001, pp. 141-169

[13] Lloyd, A. C., The California Fuel Cell Partnership: An Avenue to Clean Air, J. Power Sources, Volume 86, 2000, pp. 57-60

[14] Veyo, S.E., Shockling, L.A., Dederer, J.T., Gillett, J.E., Lundberg, W.L., ASME Paper 2000-GT-0550

[15] Magistri, L., Bozzolo, M., Tarnowski, O., Agnew, G., design and off-design analysis of a mw hybrid system based on rollsroyce integrated planar solid oxide fuel cells, journal of engineering for gas turbine and power, Volume 129, 2007, pp.792797

[16] Robert,s R. A., Brouwer, J., Dynamic Simulation of a Pressurized 220 kW Solid Oxide Fuel-Cell-Gas-Turbine Hybrid System: Modeled Performance Compared to Measured Results, Journal of Fuel Cell Science and Technology, Volume 3, 2006, pp.18-25

[17] Kitagawa, Y., Tomida, K., Nishiura, M., Hiwatashi, K., Kishizawa, H., Oozawa, H., Kobayashi, Y., Takeuchi, Y., Mihara, M., development of high efficiency sofc power generation at mhps, fuel cell seminar and energy exposition, 2015 
[18] Yi, Y., Smith, T.P., Brouwer, J., Samuelsen, G.S., Simulation of a 220 kW Hybrid SOFC gas turbine system and data comparison, Proceedings of the Eighth International Symposium on Solid Oxide Fuel Cell (SOFC-VIII), Paris, France, 2002

[19] Li, X., Ogden, J., Yang, C , Analysis of the design and economics of molten carbonate fuel cell tri-generation systems providing heat and power for commercial buildings and H2 for FC vehicles, Journal of Power Sources, Volume 241, 2015, pp. 68-73.

[20] Massardo, AF, McDonald, CF, Korakianitis, T, Microturbine/Fuel-Cell Coupling for High-Efficiency Electrical-Power Generation, J. of Eng for Gas Turbine and Power, Volume 124, 2002, pp. 110-116

[21] Yang, W.J., Park, S.K., Kim, T.S., Kim, J.H., Sohn, J.L., Ro, S.T., Design performance analysis of pressurized solid oxide fuel cell/gas turbine hybrid systems considering temperature constraints, Journal of Power Sources, Volume160, 2006, pp. $462-473$

[22] Diamantis P. Bakalis, Anastassios G. Stamatis, Optimization methodology of turbomachines for hybrid SOFC-GT applications, Energy, Volume 70, 2014, pp. 86-94

[23] Ferrari M.L., Traverso A., Massardo A.F., Smart polygeneration grids: Experimental performance curves of different prime movers, Applied Energy, Volume 162, 2016, pp. 622-630

[24] Zaccaria V., Tucker D., Traverso A., Transfer function development for SOFC/GT hybrid systems control using cold air bypass, Applied Energy, Volume 165, 2016, pp. 695-706

[25] Rivarolo M. , Cuneo A., Traverso A., Massardo A.F., Design optimisation of smart poly-generation energy districts through a model based approach, Applied Thermal Engineering, Volume 99, 2016, pp.291-301.

[26] Ferrari M.L., Pascenti M., Magistri L., Massardo A.F., MGT/HTFC hybrid system emulator test rig: Experimental investigation on the anodic recirculation system. Journal of Fuel Cell Science and Technology, Volume 8, 2011

[27] Hohloch M., Huber A., Aigner M., Experimental investigation of a SOFC/MGT Hybrid Power Plant test rig -Impact and characterization of coupling elements, ASME Turbo Expo 2014, Dusseldorf, Germany, GT2014-25918

[28] Henke M., Steilen M., Schnegelberger C., Riedel M., Hohloch M., Bücheler S., Herbst M., Huber A., Heddrich M., Kallo J., Friedrich A., Construction of a $30 \mathrm{~kW}$ SOFC Gas Turbine Hybrid Power Plant, ECS Trans. Volume 68 (1), 2015, pp.85-88

[29] A. Mawardi, R. Pitchumani, Effects of parameter uncertainty on the performance variability of proton exchange membrane (PEM) fuel cells, Journal of Power Sources Volume 160, 2006, pp. 232-245

[30] Yokokawa, H., Tu, H., Iwanschitz, B., Mai, A., Fundamental mechanisms limiting solid oxide fuel cell durability, Journal of Power Sources, Volume 182, 2008, pp. 400-412

[31] Papurello, D., Lanzini, A., Drago, D., Leone, P., Santarelli, M., Limiting factors for planar solid oxide fuel cells under different trace compound concentrations, Energy, Volume 95, 2016, pp.67- 78

[32] Hagen, A., Barfod, R., Hendriksen, P.V., Degradation of Anode Supported SOFCs as a Function of Temperature and Current Load, J. of Electrochem. Soc., Volume 153, 2006

[33] Zaccaria V., Tucker D., Traverso A., Operating strategies to minimize fuel cell degradation in SOFC gas turbine hybrids," Applied Energy, Volume 192, 2017, pp. 437 - 443

[34] Zaccaria V., Tucker D., Traverso A., Gas turbine advanced power systems to improve SOFC economic viability, Journal of Gas Power Propulsion Society, Volume 1, 2017, pp. 14-25

[35] Hughes, D., Wepfer, W.J., Davies, K., Ford, J.C., Haynes, C., Tucker, D., A real-time spatial SOFC model for hardware based simulation of hybrid systems, International ASME Conference on Fuel Cell Science, Engineering and Technology, 2011

[36] Tucker, D., Shelton, M., Manivannan, A.,The role of solid oxide fuel cells in advanced hybrid power systems of the future, The Electrochemical Society Interface, Fall 2009, pp.25-28

[37] Weimar, M., Chick, L., Gotthold, D., Whyatt, G., Cost study for manufacturing of solid oxide fuel cell power systems, U.S. Department of Energy, Sep: 24-50, Report number PNNL-22732, 2013

[38] Zaccaria, V., Tucker, D., Traverso, T., A distributed real-time model of degradation in a solid oxide fuel cell, part I: Model characterization, Journal of Power Sources Volume 311, 2016, pp.175-1816

[39] Xiu, D., Lucor, D., Su, C.-H., and Karniadakis, G. E., Stochastic modeling of flow-structure interaction using generalized polynomial chaos, ICOSAHOM-01, 2002

[40] V. Zaccaria, D. Tucker, A. TraversoA Real-time Degradation Model for Hardware in the Loop Simulation of Fuel Cell Gas Turbine Hybrid Systems, Proceedings of ASME Turbo Expo (2015), Montreal, Canada, Paper number GT2015-43604

[41] Rosa do Nascimento, M.A., de Oliveira, L., dos Santos, E.C., Gomes, E.E.B., Fagner, Dias, L.S., Velásques E.I.G., Alexis, R., Carrillo, M., Micro Gas Turbine Engine: A Review, Progress in Gas Turbine Performance, 2013, Dr. Ernesto Benini (Ed.), InTech Performance, Dr. Ernesto Benini (Ed.), InTech

[42] A. Nakajo, F. Mueller, J. Brouwer, J. van Herle, D. Favrat, Progressive activation of degradation processes in solid oxide fuel cells stacks: Part I: Lifetime extension by optimisation of the operating conditions, Journal of Power Sources 216 (2012) 449-463

[43] Weimar, M., Chick, L., Gotthold, D., Whyatt, G., Cost study for manufacturing of solid oxide fuel cell power systems, U.S. Department of Energy, Sep: 24-50, Report number PNNL-22732, 2013

[44] United States Natural Gas Industrial Prices, https://www.eia.gov/dnav/ng/hist/n3035us3m.html (last access 27/02/2018)

[45] Capstone, Product Specification Models C600, C800, and C1000 Capstone MicroTurbine, 460051 Rev. D (July 2009)

[46] https://it.mathworks.com/help/gads/genetic-algorithm.html?requestedDomain=true (last access 27/02/2018)

[47] H. Sayyaadi, Multi-objective approach in thermoenvironomic optimization of a benchmark cogeneration system, Appl Energy, 86 (6) (2009), pp. 867-879

[48] V. Zaccaria, A. Cuneo, A. Sorce, 2018, "Influence of Multiple Degrading Components on Gas Turbine Fuel Cell Hybrid System Lifetime”, GPPS Forum 2018, pp.1-9, Zurich, Switzerland. 